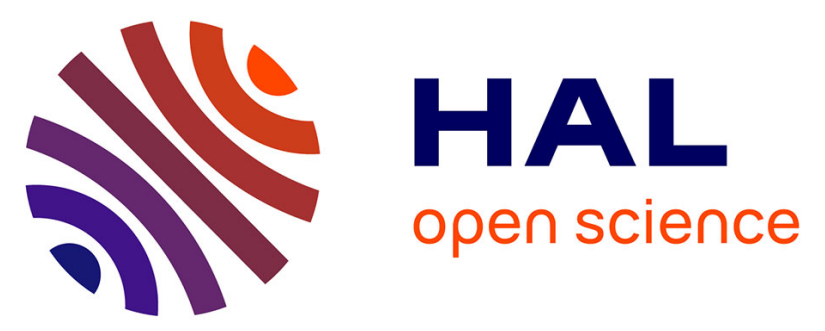

\title{
Bio-catalytic action of twin-screw extruder enzymatic hydrolysis on the deconstruction of annual plant material: case of sweet corn co-products
}

\author{
Virginie Vandenbossche, Julien Brault, Gérard Vilarem, Luc Rigal
}

\section{To cite this version:}

Virginie Vandenbossche, Julien Brault, Gérard Vilarem, Luc Rigal. Bio-catalytic action of twin-screw extruder enzymatic hydrolysis on the deconstruction of annual plant material: case of sweet corn coproducts. Industrial Crops and Products, 2015, vol. 67, pp. 239 -248. 10.1016/j.indcrop.2015.01.041 . hal-01122012

\section{HAL Id: hal-01122012 \\ https://hal.science/hal-01122012}

Submitted on 3 Mar 2015

HAL is a multi-disciplinary open access archive for the deposit and dissemination of scientific research documents, whether they are published or not. The documents may come from teaching and research institutions in France or abroad, or from public or private research centers.
L'archive ouverte pluridisciplinaire HAL, est destinée au dépôt et à la diffusion de documents scientifiques de niveau recherche, publiés ou non, émanant des établissements d'enseignement et de recherche français ou étrangers, des laboratoires publics ou privés. 


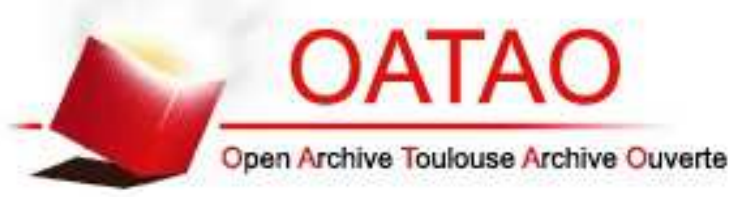

\section{Open Archive TOULOUSE Archive Ouverte (OATAO)}

OATAO is an open access repository that collects the work of Toulouse researchers and makes it freely available over the web where possible.

This is an author-deposited version published in : http://oatao.univ-toulouse.fr/ Eprints ID : 13605

To link to this article : DOI:10.1016/j.indcrop.2015.01.041 URL : http://dx.doi.org/10.1016/j.indcrop.2015.01.041

\section{To cite this version :}

Vandenbossche, Virginie and Brault, Julien and Vilarem, Gérard and Rigal, Luc Bio-catalytic action of twin-screw extruder enzymatic hydrolysis on the deconstruction of annual plant material: case of sweet corn co-products. (2015) Industrial Crops and Products, vol. 67 . pp. 239 -248. ISSN 0926-6690

Any correspondance concerning this service should be sent to the repository administrator: staff-oatao@ listes-diff.inp-toulouse.fr 


\title{
Bio-catalytic action of twin-screw extruder enzymatic hydrolysis on the deconstruction of annual plant material: Case of sweet corn co-products
}

\author{
Virginie Vandenbossche $^{\mathrm{a}, \mathrm{b}, *}$, Julien Braulta ${ }^{\mathrm{a}, \mathrm{b}}$, Gérard Vilarem ${ }^{\mathrm{a}, \mathrm{b}}$, Luc Rigal ${ }^{\mathrm{a}, \mathrm{b}}$ \\ a Université de Toulouse, INP, Laboratoire de Chimie Agro-Industrielle, ENSIACET, 4 Allée Emile Monso, BP 44362, 31030 Toulouse Cedex 4, France \\ ${ }^{\mathrm{b}}$ INRA, Laboratoire de Chimie Agro-Industrielle, 31030 Toulouse Cedex 4, France
}

Keywords:

Sweet corn co-product

Twin-screw extruder

Enzymatic hydrolysis

Bioextrusion

Alkaline pre-treatment

\begin{abstract}
A B S T R A C T
A continuous process combining an alkaline thermo-mechano-chemical pretreatment neutralization step, followed by injection of enzymes into the twin-screw extruder, was developed using sweet corn co-products as a biomass model. The implementation of the continuous process is described. Particular attention is paid to the influence of the bio-catalytic action of enzymatic hydrolysis on the deconstruction of annual plant material in the twin-screw extruder (a process called "bioextrusion"). The use of a twinscrew extruder allows working with high consistency (20\%), in a high shear environment, for a short time ( $\sim 2 \mathrm{~min}$ ). In the present work, the nature of the ligno(hemi)cellulosic material transformations, covering solubilization and extraction of saccharides and modification of cellulosic fibers, were investigated. $41 \%$ of hemicelluloses and $14 \%$ of lignin are extracted by the alkaline pretreatment. Hydrolytic enzymes are not deactivated during bioextrusion, which has a destructing effect on the fiber. It leads to a change of rheological properties and induces an increase of sugars released in the form of mono and polysaccharides (up to 13\%/DM of total sugars) with longer chains than in the case of a batch reactor. At the same time, the degree of polymerization decreases and a shortening of the cellulose chains occurs.
\end{abstract}

\section{Introduction}

The lignocellulosic materials from agriculture and forest by-products represent an important source of renewable and carbon-neutral energy. These resources are clean, cheap, available in large quantities, and are independent of geographical location, plus they are carbon neutral and renewable. However, the lignocellulosic biomass is a complex assembly of cellulose, hemicelluloses and lignin whose extraction and conversion requires the use of a refining process (Himmel et al., 2007).

These transformation processes are actually studied worldwide and many reviews exist on the subject (Van Dyk and Pletschke 2012). They are typically realized in two steps: one of pretreatment intended to improve the accessibility of the cellulose and a second allowing hydrolysis of the cellulose by enzymatic action. Sun and Cheng, 2002, Mosier et al. (2005), Zheng et al. (2009), Harmsen et al. (2010) and Alvira et al. (2010) have reviewed pre-treatment tech-

\footnotetext{
* Corresponding author at: Université de Toulouse, INP, Laboratoire de Chimie Agro-Industrielle, ENSIACET, 4 Allée Emile Monso, BP 44362, 31030 Toulouse Cedex 4, France. Tel.: +33 5343235 49; fax: +33 534323599 .

E-mail address: Virginie.Vandenbossche@ensiacet.fr (V. Vandenbossche).
}

nologies for a bioethanol production process based on enzymatic hydrolysis. Most cited pretreatments, among which dilute acid pretreatment (Saha et al., 2005), steam explosion (Oliva et al., 2003; Cara et al., 2006; Varga et al., 2004; Ballesteros et al., 2006) and ammonia fiber explosion (Galbe and Zacchi, 2007) are the most well known, are penalized by implementation constraints, technology or reagent costs, or inhibitor production for enzymatic hydrolysis or ethanolic fermentation.

Soft alkaline pretreatment is one approach that has several potential advantages compared to other pretreatment processes, including lower operating cost, reduced degradation of holocellulose, and subsequent formation of inhibitors for downstream processing (Carvalheiro et al., 2008; Kumar et al., 2009; McIntosh and Vancov, 2011; Taherzadeh and Karimi, 2008). The main mechanisms of soft alkaline pretreatment are hydroxyl group solvation, leading to the rupture of intra or inter molecular hydrogen bonds, and the breakdown of ester bonds with cleavage of linkages in the lignocellulosic cell wall matrix, all of which lead to the alteration of the lignin structure, the hydrolysis of the lignin-hemicellulose complex, cellulose swelling, and the partial decrystallization of the cellulose (Bobleter, 1994; Sun and Cheng, 2002).

A way to improve process costs is to increase the solid concentration of biomass in each unit operation. Such high solid 


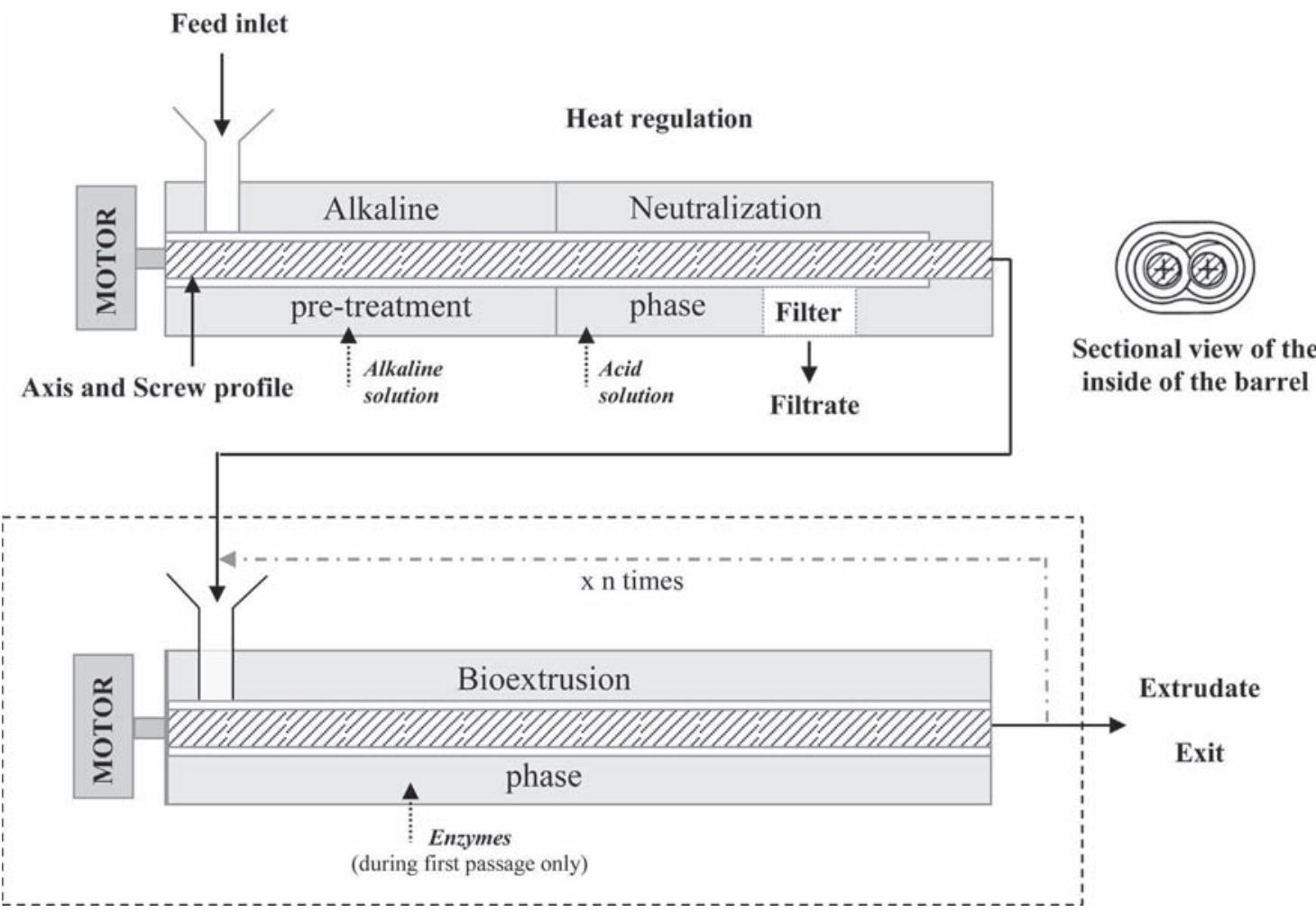

Fig. 1. Schematic representation of the sequences of the process carried out in two successive twin screw extruders with recirculation of the bioextrudate in the second twin screw extruder with or without a filtration module.

concentrations dramatically increase economic viability, reducing operating costs due to decreased volumes. However, increasing solid concentration increases the apparent viscosity of biomass slurries, making mixing and conveying operations more challenging. Among the processes used to carry out pretreatment with a minimum number of steps, twin-screw extrusion technology has many advantages and allows working with high solid concentrations. It produces a high shear, rapid heat transfer, and effective and rapid mixing, in a continuous operation, with good adjustability of treatment steps.

Co-penetrating and co-rotating twin-screw extruders are most common (Dziezak, 1989), and a very wide choice of screw elements is available. The screw profile is defined by the arrangement of the different screw elements and their characteristics (pitch, length, number and shape of screw, and angle between two successive elements in case of paddle screws) in different positions and spaced differently.

The performance of twin-screw extrusion and the influence of the operating parameters have been studied on biomass fractionation from poplar (N'Diaye and Rigal, 2000), Miscanthus sp. (De Vrije et al., 2002), sugar beet pulp (Rouilly et al., 2006), sunflower (Evon et al., 2007; Kartika et al., 2006), soybean hulls (Yoo et al., 2011), rice straw (Chen et al., 2011), and wheat straw and bran (Marechal et al., 2004; Zeitoun et al., 2010; Vandenbossche et al., 2014a).

More particularly, twin-screw extrusion can be used to pretreat different biomasses for the production of sugars, and several authors have reported this type of application over the last few

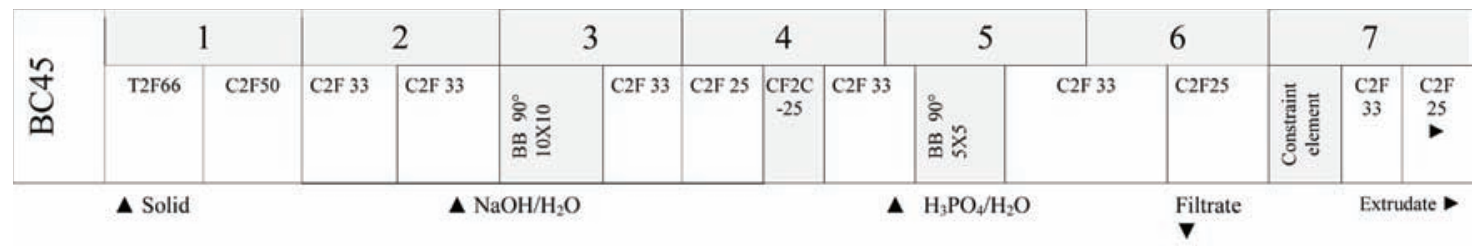

Alkaline pretreatment

\begin{tabular}{|c|c|c|c|c|c|c|c|c|c|c|c|c|c|c|}
\hline \multirow[b]{2}{*}{$\bar{ల}$} & \multirow{2}{*}{$\begin{array}{c}8 \\
\text { T2F66 }\end{array}$} & \multirow{2}{*}{$\frac{9}{\mathrm{C} 2 \mathrm{~F} 33}$} & 10 & \multicolumn{2}{|c|}{11} & \multicolumn{3}{|c|}{12} & \multicolumn{3}{|c|}{13} & \multicolumn{3}{|c|}{14} \\
\hline & & & $\begin{array}{l}\text { ¿े음 } \\
\text { 씽 }\end{array}$ & C2F 25 & C2F 16 & 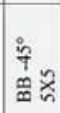 & C2F 25 & $\begin{array}{l}\text { C2F } \\
16\end{array}$ & 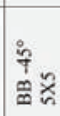 & $\begin{array}{l}\mathrm{C} 2 \mathrm{~F} \\
25\end{array}$ & $\begin{array}{l}\mathrm{C} 2 \mathrm{~F} \\
16\end{array}$ & 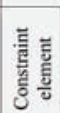 & $\begin{array}{l}\mathrm{C} 2 \mathrm{~F} \\
25\end{array}$ & $\stackrel{\mathrm{C} 2 \mathrm{~F}}{ } 33$ \\
\hline
\end{tabular}

Bioextrusion

Fig. 2. Screw configuration for the combined process of pretreatment and bioextrusion with or without liquid/solid separation zone. (T2F=trapezoidal double-thread screw; $\mathrm{C} 2 \mathrm{~F}=$ conveying double-thread screw; $\mathrm{BB}=$ bilobe paddle screw; $\mathrm{CF} 2 \mathrm{C}=$ reversed double-thread screw. The numbers following the type of the screw indicate the pitch of $\mathrm{T} 2 \mathrm{~F}$, $\mathrm{C} 2 \mathrm{~F}$, and CF2C screws or the angle between two successive elements in case of BB screws). 
Table 1

Operating conditions.

\begin{tabular}{|c|c|c|c|c|c|c|c|c|c|c|}
\hline Profile & Constraintelements & $\begin{array}{l}\mathrm{S}_{\mathrm{S}} \\
(\mathrm{rpm})\end{array}$ & $\begin{array}{l}T \\
\left({ }^{\circ} \mathrm{C}\right)\end{array}$ & $\begin{array}{l}\mathrm{NaOH} / \mathrm{DM} \\
(\%)\end{array}$ & $\begin{array}{l}\text { H3PO4/DM } \\
(\%)\end{array}$ & $\mathrm{pH}_{\mathrm{ex}}$ & $\begin{array}{l}\mathrm{L} / \mathrm{S} \\
\left(\mathrm{kg} \mathrm{h}^{-1} / \mathrm{kg} \mathrm{h}^{-1}\right)\end{array}$ & FR & $\begin{array}{l}I \\
(\mathrm{~A})\end{array}$ & Stability \\
\hline \multirow[t]{3}{*}{ A 1} & CF2C -25 & 110 & 100 & 32.4 & 36.6 & 7.0 & 10.3 & 0.06 & 9 & Instability of dynamic plug \\
\hline & & 100 & 100 & 10.7 & 13.1 & 6.5 & 3.6 & 0.20 & 23 & $\begin{array}{l}\text { Instability } \\
\text { filtration maintained but } \\
\text { irregular }\end{array}$ \\
\hline & & 110 & 100 & 9.4 & 11.0 & 6.0 & 7.6 & 0.08 & 17 & $\begin{array}{l}\text { Instability } \\
\text { filtration maintained but } \\
\text { irregular }\end{array}$ \\
\hline \multirow[t]{3}{*}{ A 2} & CF1C -25 & 110 & 100 & 10.5 & 11.8 & 6.0 & 8.2 & 0.07 & 17 & Stable \\
\hline & & 110 & 100 & 12.1 & 29.4 & 5.0 & 8.4 & 0.08 & 21 & Stable \\
\hline & & 110 & 100 & 18.6 & 28.0 & 5.5 & 8.1 & 0.07 & 14 & Stable \\
\hline
\end{tabular}

Constraint elements and operating conditions for Alkaline pre-treatment (CF2C = reversed double-thread screw, CF1C = reversed simple-thread screw, DM is the dry matter of inlet sweet corn, $\mathrm{Ss}$ is the screw rotation speed (rpm), $\mathrm{pH}_{\mathrm{ex}}$ is the $\mathrm{pH}$ of the extrudate, $\mathrm{L} / \mathrm{S}$ is the liquid/solid ratio, FR is the extruder filling ratio, $I$ is the current feeding the $\operatorname{motor}(\mathrm{A})$.

Table 2

Constraint elements and operating conditions for Bioextrusion step.

\begin{tabular}{lllllll}
\hline Profile & Constraint elements & $\begin{array}{l}\mathrm{S} \\
(\mathrm{rpm})\end{array}$ & $\begin{array}{l}T \\
\left({ }^{\circ} \mathrm{C}\right)\end{array}$ & $\begin{array}{l}\text { Enzyme/DM } \\
(\%)\end{array}$ & $\begin{array}{l}\text { L/S } \\
\left(\mathrm{kg} \mathrm{h}^{-1} / \mathrm{kg} \mathrm{h}^{-1}\right)\end{array}$ \\
\hline B 1 & CF2C $-33(25)$ & 280 & 50 & 4.0 & 2.5 & Stability \\
B 2 & CF2C -33 (50) & 280 & 50 & 4.0 & 2.5 & 0.01 \\
B 3 & CF2C $-16(25)$ & 200 & 50 & 4.1 & 2.5 & 0.01 \\
B 4 & DM $-45^{\circ}(5 \times 5)$ & 200 & 50 & 4.6 & 2.5 & Instabilityof dynamic plug \\
\hline
\end{tabular}

$\mathrm{CF} 2 \mathrm{C}=$ reversed double-thread screw, $\mathrm{DM}=$ monolobe paddle-screw, the length of the screws is indicated in brackets, $\mathrm{FR}=$ extruder filling ratio.

years. Zheng and Rehmann (2014) provide an overview of the extrusion pretreatment of lignocellulosic biomass.

Lamsal et al. (2010) first showed that extrusion led to higher reducing sugar yields compared to grinding, and they studied the process on wheat bran in two steps: impregnation with water followed by mechanical treatment (grinding or extrusion). A combination of both extrusion and alkaline pretreatment has been explored more recently (Zhang et al., 2012; Karunanithy and Muthukumarappan, 2011; Duque et al., 2013; Um et al., 2013; Kang et al., 2013; Han et al., 2013). Karunanithy and Muthukumarappan, 2013 provide an overview of this type of thermo-mechanical pretreatment, including the mechanism influencing extruder and feedstock parameters, plus evaluation of pretreatment efficiency. A continuous process combining alkaline thermo-mechano-chemical pretreatment, followed by injection of enzymes into the twinscrew extruder, called "bioextrusion" was developed and tested on different biomass such as sweet corn residue (SC), blue agave bagasse, oil palm empty fruit bunch as residue from palm oil manufacture, and barley straw (Vandenbossche et al., 2014b; Duque et al., 2014). This new process leads to excellent mixing of the enzymes with the pretreated biomass at high concentrations, and allows saccharification to begin during bioextrusion.

The implementation of the continuous process, and the influence of the bio-catalytic action of hydrolytic enzymes on deconstruction of annual plant material in the twin-screw extruder during "bioextrusion", is studied here in case of a weakly lignified material: the sweet corn co-products.

\section{Experimental}

\subsection{Materials}

\subsubsection{Feedstocks}

Dehydrated sweet corn co-products, provided by SARL Soupro+, came from an industrial corn grain cannery. It was milled using a hammer mill fitted with a $6 \mathrm{~mm}$ screen, and contained $4 \%$ ash, $39 \%$ cellulose, 36\% hemicelluloses and 4\% lignin (all expressed in $\% /$ dry matter and determined according to the French standard NF V 03-322 and ADF-NDF method cited in Section 2.3).

\subsubsection{Enzymatic cocktails}

Enzymatic saccharification was conducted using the Saccharised C6 cocktail from Advanced Enzyme Technologies (India) in a citrate buffer $(300 \mathrm{mM}, \mathrm{pH} 4.8)$. A solution of $1 \%$ of saccharised C6 cocktail is characterized by: protein content of $9 \mathrm{mg} / \mathrm{ml}$, cellulose activity of 5s 5FPU/ml, endoglucanase activity of $1940 \mathrm{nkat} / \mathrm{ml}$, xylanase acivity of $16,900 \mathrm{nkat} / \mathrm{ml}$, and $\beta$-glucosidase activity of $310 \mathrm{nkat} / \mathrm{ml}$. The protein content was measured after acetone precipitation with Bio-Rad DC protein assay kit, cellulose and endoglucanase activity according to Ghose (1987), xylanase activity according to Bailey et al. (1992) and $\beta$-glucosidase activity according to Bailey and Nevalainen (1981).

A preliminary study showed that the mixture of advance enzyme had an optimum temperature at $54^{\circ} \mathrm{C}$. Beyond $56^{\circ} \mathrm{C}$ enzyme activity begins to decrease, to keep a safety margin we placed at $50^{\circ} \mathrm{C}$ for the bioextrusion trials.

\subsection{Twin-screw extruder}

Thermo- mechano-chemical alkaline pre-treatment and the neutralization phase, were conducted using a co-penetrating and co-rotating Clextral BC 45 twin-screw extruder. For the bioextrustion phase a Clextral BC 21 is used. Both BC 45 and BC 21 had seven modular barrels, each of these measuring $200 \mathrm{~mm}$ in length for BC 45 and $100 \mathrm{~mm}$ for BC21. Both extruders were equipped with different segmental screw elements. The metallurgy is, respectively, CLX200 for BC45 and hastelloy for BC21. Both are corrosion resistant. Modules were thermo-regulated by thermal induction for $\mathrm{BC} 45$ and by heater band for $\mathrm{BC} 21$; module cooling was by water circulation. A filter section was used to enable the filtrate to be collected and consisted of six hemispherical dishes with conical holes ( $1 \mathrm{~mm}$ entry, $2 \mathrm{~mm}$ exit). The outputs of extruders were not equipped with die. Schematic representation of the sequence of steps for the process carried out in two successive twin-screw extruders is shown in Fig 1. Screw configuration for the combined process of pretreatment and bioextrusion is shown in Fig 2. After alkaline pretreatment and neutralization in twin-screw extruder $\mathrm{BC} 45$, the extrudate was stored frozen and defrosted just before being introduced into BC 21 for the bioextrusion. 
Table 3

Operating conditions for alkaline pre-treatment and bioextrusion.

\begin{tabular}{|c|c|c|c|}
\hline \multicolumn{2}{|c|}{ Alkaline pretreatment } & \multicolumn{2}{|l|}{ Bioextrusion } \\
\hline$S_{\mathrm{S}}(\mathrm{rpm})$ & 110 & $S_{\mathrm{S}}(\mathrm{rpm})$ & 200 \\
\hline$T\left({ }^{\circ} \mathrm{C}\right)$ & 100 & $T\left({ }^{\circ} \mathrm{C}\right)$ & 50 \\
\hline$Q_{S}(\mathrm{Kg} / \mathrm{h})$ & 8.8 & $Q_{S}(\mathrm{Kg} / \mathrm{h})$ & 3.29 \\
\hline DMs (\%) & 90 & DMs (\%) & 39.6 \\
\hline$Q_{\text {LAlk }}(\mathrm{Kg} / \mathrm{h})$ & 20.7 & $Q_{T+E z}(\mathrm{~kg} / \mathrm{h})$ & 1.95 \\
\hline$Q_{\mathrm{NaOH}}(\mathrm{Kg} / \mathrm{h})$ & 0.8 & $Q_{E z}(g / h)$ & 60 \\
\hline$Q_{\mathrm{LAC}}(\mathrm{Kg} / \mathrm{h})$ & 51.6 & & \\
\hline $\mathrm{Q}_{\mathrm{H} 3 \mathrm{PO} 4}(\mathrm{Kg} / \mathrm{h})$ & 0.9 & & \\
\hline $\mathrm{NaOH} / \mathrm{DM}(\%)$ & 10.5 & Enzyme/DM (\%) & 4.6 \\
\hline $\mathrm{H}_{3} \mathrm{PO}_{4} / \mathrm{DM}(\%)$ & 11.7 & & \\
\hline $\mathrm{L} / \mathrm{S}\left(\mathrm{kg} \mathrm{h}^{-1} / \mathrm{kg} \mathrm{h}^{-1}\right)$ & 7.6 & $\mathrm{~L} / \mathrm{S}\left(\mathrm{kg} \mathrm{h}^{-1} / \mathrm{kg} \mathrm{h}^{-1}\right)$ & 2.5 \\
\hline$Q_{\text {ext }}(\mathrm{kg} / \mathrm{h})$ & 16.5 & $Q_{\text {bioext }}(\mathrm{kg} / \mathrm{h})$ & 5.29 \\
\hline $\mathrm{DM}_{\mathrm{ext}}$ & 40.7 & $\mathrm{DM}_{\text {bioext }}$ & 29.0 \\
\hline$Q_{\text {fil }}(\mathrm{kg} / \mathrm{h})$ & 62.4 & & \\
\hline $\mathrm{DM}_{\mathrm{fil}}$ & 4.7 & & \\
\hline $\mathrm{pH}_{\mathrm{ext}}$ & 6 & & \\
\hline $\mathrm{pH}_{\mathrm{fil}}$ & 5.5 & & \\
\hline$I(\mathrm{~A})$ & 17 & & \\
\hline $\mathrm{SME}(\mathrm{Wh} / \mathrm{kg})$ & 141 & & \\
\hline
\end{tabular}

Where $S_{\mathrm{S}}$ is the screw rotation speed (rpm); $T$ is the set temperature of the heating modules $\left({ }^{\circ} \mathrm{C}\right) ; Q_{S}$ and $\mathrm{DM}_{\mathrm{S}}$ are the feed rate $(\mathrm{kg} / \mathrm{h})$ and dry matter (\%) of sweet corn; $Q_{\text {LAlk }}$ and $Q_{\mathrm{LAc}}$ are respectively the inlet flow rate of alkali solution $(\mathrm{kg} / \mathrm{h})$ and acid solution $(\mathrm{kg} / \mathrm{h}) ; \mathrm{Q}_{\mathrm{NaOH}}$ and $\mathrm{Q}_{\mathrm{H} 3 \mathrm{PO} 4}$ are the inlet flow of $\mathrm{NaOH}$ and $\mathrm{H}_{3} \mathrm{O}_{4}$; $\mathrm{NaOH} / \mathrm{DM}$ and $\mathrm{H}_{3} \mathrm{PO}_{4} / \mathrm{DM}$ are the reagent to sweet corn dry matter ratio (\%); L/S is the liquid/solid ratio; $Q_{\text {ext }}, Q_{\text {bioext }}$ and $Q_{\text {fil }}$ are, respectively, the flow rate of extrudate, bioextrudate and filtrate $(\mathrm{kg} / \mathrm{h}) ; \mathrm{DM}_{\text {ext }}, \mathrm{DM}_{\text {bioext }}$ and $\mathrm{DM}_{\mathrm{fil}}$ are, respectively, the dry matter of extrudate, bioextrudate and filtrate. $I$ is the current feeding the motor (A): SME is the specific mechanical energy consumed by the motor per unit weight of solid matter $(\mathrm{Wh} / \mathrm{kg})$.

\subsubsection{Alkaline thermo-mechano-chemical pre- treatment and neutralization phase}

The alkali used for the pretreatment is sodium hydroxide $(\mathrm{NaOH})$, and the neutralization step uses phosphoric acid $\left(\mathrm{H}_{3} \mathrm{PO}_{4}\right)$. Operating conditions are described in Tables 1 and 3.

Feedstocks were fed into the extruder's first module and the alkaline solution injected using a piston pump. A first zone of mechanical pressure, consisting of a succession of bilobal paddles, ensures grinding and good mixing of the material with this alkaline solution. An acid solution was then injected using a piston pump, to neutralize the medium and reduce the viscosity of the matter to ensure good filtration. A second zone of mechanical pressure guarantees good mixing with the medium, and fast neutralization. The filtration zone situated in module 6 was carried out by a third zone of mechanical pressure using reversed pitch screws to ensure the formation of a dynamic plug, and thus the pressing of the mixture.

Table 4

Composition and enzymatic hydrolysability of the pretreated coproduct of sweet corn.

\begin{tabular}{ll}
\hline Composition & \\
\hline DM (\%) & 40,7 \\
MM (\%/DM) & 7,3 \\
OM (\%/DM) & 92,7 \\
Hot water soluble (\%/DM) & 31,4 \\
Cellulose (\%/DM) & 46,4 \\
Hemicelluloses (\%/DM) & 28,8 \\
Lignin (\%/DM) & 4,8 \\
Glucose (\%/DM) & 54,4 \\
Xylose (\%/DM) & 22,3 \\
Arabinose (\%/DM) & 3,0 \\
Galactose (\%/DM) & 0,7 \\
Mannose (\%/DM) & 0,1 \\
Enzymatic hydrolysability & \\
(\%/DM) & 35 \\
\hline
\end{tabular}

$\mathrm{DM}=$ dry matter; $\mathrm{MM}=$ mineral matter; $\mathrm{OM}=$ organic matter.

\subsubsection{Bioextrusion}

Bioextrusion consists of introducing an enzyme cocktail into the extruder, and then using a succession of compression and expansion steps to facilitate the penetration of these enzymes into the matter. Operating conditions are shown in Tables 2 and 3.

\subsection{Analytical methods}

\subsubsection{Dry matter and parietal compounds}

Moisture contents were determined according to the French standard NF V 03-903 and mineral contents according to the French standard NF V 03-322. An estimation of the three parietal constituents (cellulose, hemicelluloses, and lignins) contained in the solids, was made using the ADF-NDF method of Van Soest and Wine $(1967,1968)$. All determinations have been carried out in triplicate and standard deviation was less than $1.5 \%$ for all measurements.

An estimation of the hot water-soluble components contained, was made by measuring the mass loss of the test sample after $1 \mathrm{~h}$ in boiling water. This method has been adapted using standard TAPPI $204 \mathrm{~cm}-97$ on the Fibertec Tecator M1017 apparatus. All determinations were carried out in duplicate.

\subsubsection{Sugars}

Reducing sugars were determined using the DNS method (Miller, 1959).

Total sugars were determined after acid hydrolysis using a method adapted from NERL (Sluiter et al., 2008). $10 \mathrm{ml}$ of filtrate

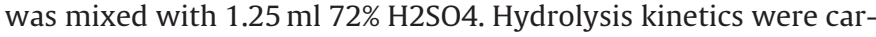
ried out in sealed tubes between 30 and $90 \mathrm{~min}$ at $100^{\circ} \mathrm{C}$. After cooling, samples were neutralized with $3.6 \mathrm{ml} \mathrm{NaOH} 32 \%(\mathrm{~m} / \mathrm{v})$, diluted and filtered $(0.45 \mu \mathrm{m})$. Analysis was then made using highperformance liquid chromatography (HPLC).

Free and total sugars were measured using HPLIC (DIONEX ICS3000 coupled with pulsed amperometric detection (PAD) and fitted with a Carbopac PA1 column).

Enzymatic hydrolysability was determined by enzymatic hydrolysis in $50 \mathrm{mM}$ citrate phosphate buffer ( $\mathrm{pH} 4.6$ ) in the presence of Advanced enzymes (2.5\%/DM substrate) at $50{ }^{\circ} \mathrm{C}$ for $48 \mathrm{~h}$. It has been calculated as the percentage of reducing sugars released by enzymatic hydrolysis, relative to dry matter.

Sugars released after bioextrusion were measured on water solubles extracted from bioextrudates. The latter, obtained after 1, 3, 5 or 7 passages in the BC21 twin-screw extruder, were first diluted in water with a Liquid/Solid ratio of 20 and then filtered onto a glass filter (porosity grade: 2 ).

\subsubsection{Degree of polymerization (DP) of oligosaccharides}

The degree of polymerization (DP) of oligosaccharides was determined in high performance anion-exchange chromatography equipped with a pulsed amperometric detector and an eluent generator EluGen ${ }^{\circledR}$ (HPAEC-PAD, ICS-3000, Dionex). The analyses were carried out with an anion exchange column (250 mm Carbopac PA200) and used a mixture of two eluents (A:100 mM sodium hydroxide and $B: 100 \mathrm{mM}$ sodium hydroxide with $1 \mathrm{M}$ sodium acetate) with a gradient from $100 \%$ of $A$ at $t=0$ to $75 \%$ of $A$ and $25 \%$ of $\mathrm{B}$ at $t=35 \mathrm{~min}$. The flow rate of the column was fixed at $0.35 \mathrm{~mL} / \mathrm{min}$.

\subsubsection{Residence time distribution (RTD)}

Sweet corn particles colored with Erythrosin were placed quickly $(<2 s)$ on the first screw element. This dye was chosen as a tracer for its neutral characteristics with respect to the process and because of its good colorization of most vegetable matter, itself often highly colored (N'Diaye, 1996). Samples of extrudate are taken every $5 \mathrm{~s}$ at the solid outlets of the extruder. All samples are dried at $103{ }^{\circ} \mathrm{C}$ and ground to homogenize the color and 


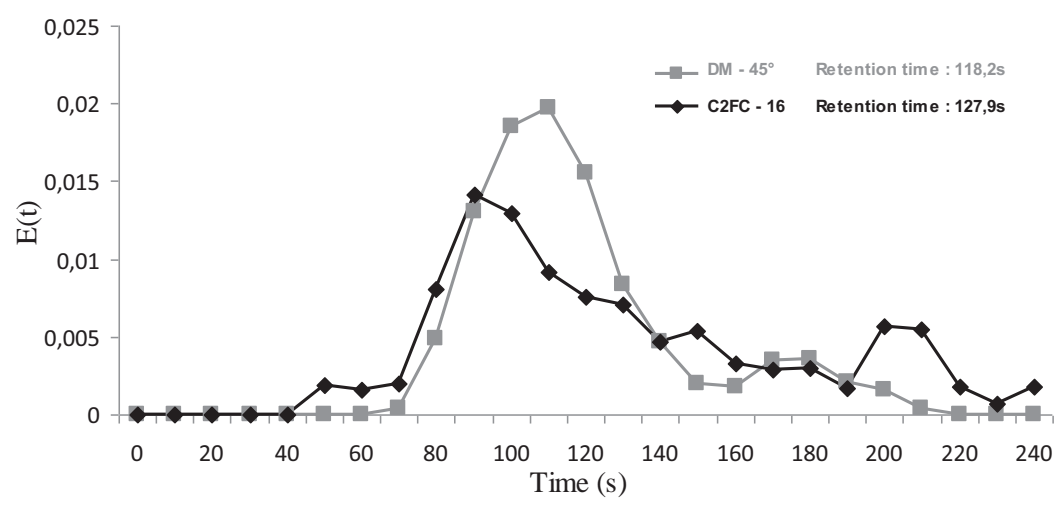

Fig. 3. Residence time distribution (RTD) of the material in the BC21 twin-screw extruder equipped with profiles B3 and B4.

to eliminate large size particles which affect measurements. The ' $a$ ' coordinate of colored outlet samples in the CIE $\left(L^{*} a^{*} b\right)$ system, is read directly using a spectrophotocolorimeter (Model CM 500i, Minolta, Japan, illuminant: D65, observer angle: $2^{\circ}$ ). The RTD data are examined through typical distribution versus time plots. RTD is defined as:

$$
E \mathrm{i}=\frac{C \mathrm{i}}{\sum_{i=1}^{n} C \mathrm{i} \times D \mathrm{t}}
$$

where $\mathrm{Ci}$ is the tracer concentration in each sample and $\mathrm{Dt}$ is the sampling period. Typical curves are shown on (Fig. 3).

\subsubsection{Dynamic viscosity}

Viscosity values were determined in accordance with TAPPI Standard T 230 om-94 "viscosity of pulp" (capillary viscometer method). In our case, the sample was solvated with cupriethylenediamine and passed through a canon-fenske Viscometer, type 150 at $25^{\circ} \mathrm{C}$. The viscometer readings were performed three times for each sample.

\section{Results and discussion}

The process of deconstruction of lignocellulosic plant material is carried out using two consecutive extruders BC 45 and BC 21. It included three different parts: an alkaline pre-treatment (in $\mathrm{BC}$ 45), a neutralization phase (in BC 45), and an enzyme impregnation phase (bioextrusion, in BC 21) during which the hemicelluloses and cellulose saccharification began. (Figs. 1 and 2).

\subsection{Alkaline pre-treatment and neutralization phase}

The first step of the process is the destructuration of cellulosic material under alkaline conditions.

The alkaline extraction conditions for hemicelluloses and lignin in twin-screw extruders have been widely studied, for instance on sorghum and poplar wood fibers (N'Diaye et al., 1996) or on wheat straw (Magro, 1995; Marechal, 2001; Zeitoun et al., 2010), and this previous work has allowed us to define the configuration and screw profiles used in this study. The aim of this first step is to open up the complex structure of the biomass, and facilitate access of the hydrolytic enzymes to polysaccharides, by increasing the surface area (Karunanithy and Muthukumarappan 2011) and porosity (Zhang et al., 2012; Vandenbossche et al., 2014b).

The thermomechanical effect of the flow restricting elements of the screw profile, ensures physical disintegration of the material by separating the fiber bundles. The presence of sodium hydroxide ensures additional chemical destructuration by solubilization of organic matter, especially hemicelluloses and lignin, depending on the amount used.

The neutralization phase is necessary to obtain a $\mathrm{pH}$ compatible with effective enzyme activity during bioextrusion. Phosphoric acid is used in this step because it is triprotic and so limits the mass of acid needed. This neutralization step also decreases the viscosity of the matter via a change of $\mathrm{pH}$ and a dilution effect, which facilitates filtration and plays a part in developing friction, shear, and impacts residence time. The effectiveness of the filtration step depends on the formation and stability of the "dynamic plug" formed in module 7 , and to the presence of constraint elements (Fig. 2). The selection of these constraint elements is important for the formation of a stable "dynamic plug". The use of a C2FC -25 reversed double-thread screw failed to achieve a stable filtration despite varying the operating conditions, including a change in the amount of sodium hydroxide, in the liquid-solid ratio, or in the degree of filling (Table 1). Indeed, in the presence of insufficient backpressure, the operation of the extruder as a liquid/solid separator may be cyclic, with an accumulation of fluid in the filtration zone resulting in a loss of dynamic plug structure. Liquid separation is less effective and the solid is insufficiently pressed. This is accentuated in the presence of high levels of sodium or high liquid/solid ratios and can explain the worst results, obtained with a $\mathrm{NaOH} / \mathrm{DM}$ ratio of $32.4 \%$. A change in extruder configuration, consisting of replacing the $\mathrm{C} 2 \mathrm{FC}-25$ reversed double-thread screw with a reversed simple-thread screw C1FC -25 , has achieved a steady state for a $\mathrm{L} / \mathrm{S}$ ratio close to 8 , a filling ratio $(\mathrm{Q} / \mathrm{S})$ of $0.07-0.08$ and for a range of $\mathrm{NaOH} / \mathrm{DM}$ ratios between $10 \%$ and $19 \%$. The reversed simple-thread screw C1FC -25 ensured better back pressure than the $\mathrm{C} 2 \mathrm{FC}-25$ reversed double-thread screw. For subsequent work a minimum $\mathrm{NaOH} / \mathrm{DM}$ ratio of $10.5 \%$ has been retained. Under these conditions, $8 \%$ of the cellulose is driven into the filtrate, and $41 \%$ of the hemicelluloses plus $14 \%$ of the lignins are extracted by the alkaline pretreatment including neutralization step (Table 4). The $\mathrm{pH}$ of the filtrate and of the extrudate at the end of this step is, respectively, of 5.5 and 6 .

\subsection{Development of the impregnation profile on $B C 21$}

After the alkaline pretreatment and the neutralization step, enzymes are introduced into the conveying zone of the bioextrusion step (Fig. 2), and impregnation of the material is ensured by the use of a series of mechanical pressure and relaxation zones. Four constraint zones are implemented in modules 10,12-14. The first three consist of a series of bilobe paddle screws, the first mounted at an angle of $90^{\circ}$ (no conveying effect), and the last two at $-45^{\circ}$ (retention effect on the material). The fourth zone is formed either by a reversed screw or by a monolobe paddle screw mounted at an angle of $-45^{\circ}$. These constraint elements provide good mix- 


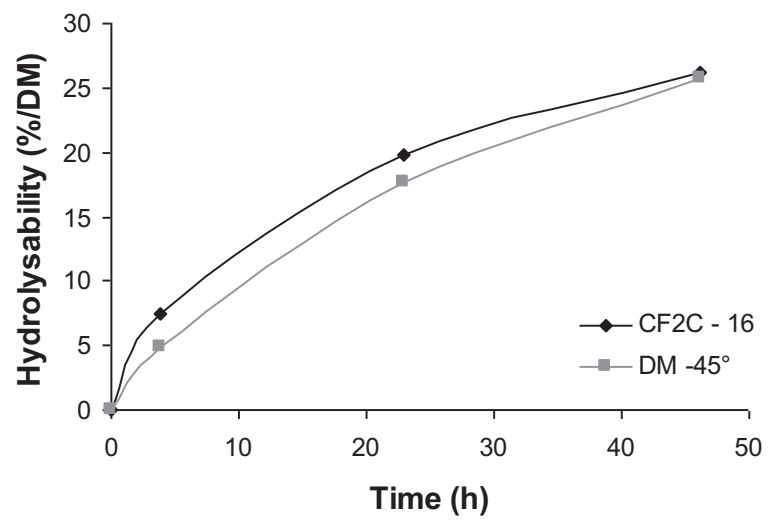

Fig. 4. Enzymatic hydrolysability kinetics of the extrudate produced by profile B3 and B4.

ing of the material. Between these areas of mechanical pressure, conveying elements with decreasing pitch ensure the transport of the mixture. In order to increase the residence time and optimize the biomass - enzyme contact, different constraint elements have been tested in module 14 (Tables 1 and 2). The reversed doublethread screws C2FC -33 generated insufficient backpressure to form a stable "dynamic plug", whatever the length tested. Reversed screws with shorter pitch or monolobe paddle-screws were used and allowed a steady state to be achieved. The determination of the residence time distribution of the matter in the extruder for these two profiles B 3 and B 4, showed that the use of monolobe paddle-screws resulted in a lower axial dispersion of residence time as well as a slight shortening thereof. However, in both cases the retention time is very similar, close to two minutes (Fig. 3). Comparison of the yields of sugars released by enzymatic hydrolysis at a low concentration $(2.5 \%$,) without adding fresh enzymes, revealed no significant difference after $48 \mathrm{~h}$ (Fig. 4). At most, the hydrolysis kinetic was initially slightly accelerated. This result also showed that the implementation of a shearing element such as reversed screws, does not cause significant deactivation of the enzymes.

\subsection{Increase in the residence time of the enzyme impregnation step: bioextrusion}

As can be seen from Fig. 3 the residence time of the material in the $\mathrm{BC} 21$ for the bioextrusion step is very close to 2 min whatever the restricting element used. This is very low compared to the times required for a significant increase in enzymatic hydrolysis for release of the monosaccharides. Thus, to understand and validate the action of enzymes in the extruder it is necessary to extend their action time during bioextrusion. The increased extruder contact time is simulated by recirculating the bioextrudate in BC21. The operation is undertaken using the same configuration and the same screw profile as for the first passage (Figs. 1 and 2), but without further addition of enzyme solution. It is as if the duration of the contact time was multiplied by the number of passages through the extruder.

The material is worked on more and more with successive passages through the extruder, and becomes sticky. This pasty consistence is less and less textured, the material is liquefied gradually, and its rheological properties change. And this change in rheology tends to prove that a fiber destructuring effect is occurring during bioextrusion, which was also observed by Samaniuk et al. (2011), who have shown a synergistic relationship between mixing and enzyme activity during enzymatic hydrolysis. And by using a torque rheometer, they demonstrated that the torque required for mixing biomass samples with $20 \%$ solid dry matter, decreases in the presence of enzymes as a function of time, and this is accompanied by an increase in glucose converted.

\subsection{Nature of the transformations of the lignocellulosic material in the twin-screw extruder during enzyme impregnation}

\subsubsection{Solubilization and extraction of saccharides}

To study the impact of bioextrusion on the evolution of the matter destructuration, an analysis of dissolved compounds during this bioextrusion is made. To this end, samples of bioextrudate are collected after each passage through the BC 21 extruder, and then diluted in water, with a liquid/solid ratio (L/S) of 20 . They are then pressed and filtered. Free sugars, reducing sugars and total sugars are then measured in the recovered filtrates.

To compare the thermomechanical effects with the thermomechanical effects coupled to enzymatic action, a test is carried out without the addition of enzyme, maintaining a solid liquid ratio of 2.5 by addition of water. Analysis of the resultant filtrate from the tests without enzyme, shows that very few saccharides are extracted during extrusion whatever the number of bioextrusion passages (Fig. 5). The thermomechanical effect generated by extrusion under these operating conditions does not act on the release of sugars, either in free form or in polysaccharide form.

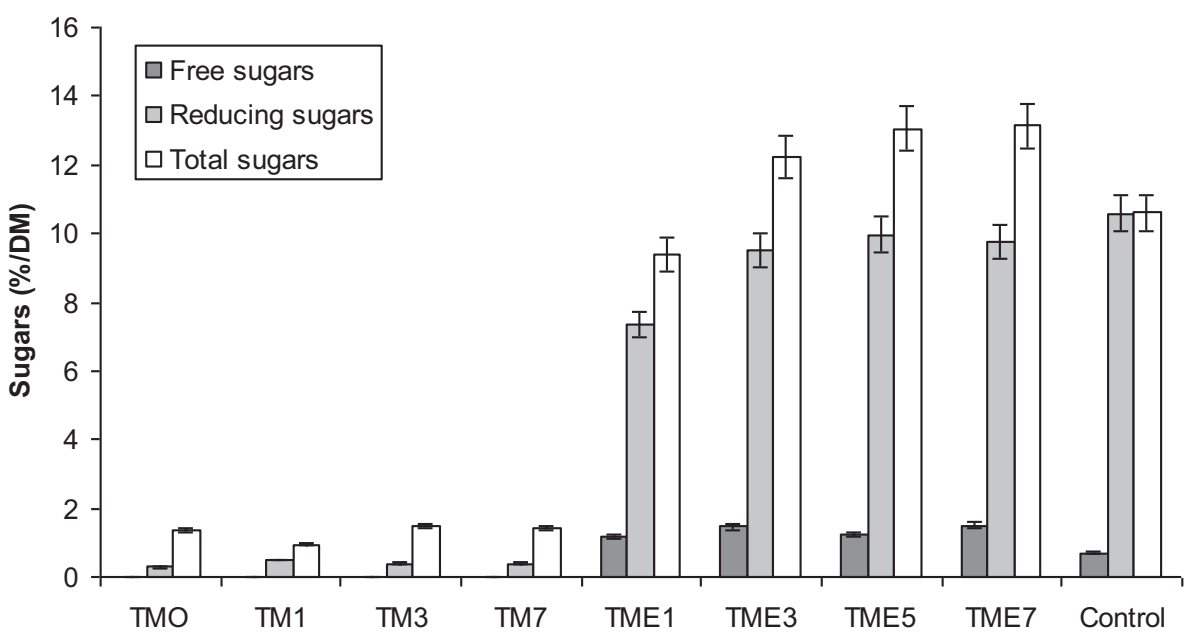

Fig. 5. Sugar released in bioextrudate after 1, 3, 5 or 7 passages through the twin screw extruder with only thermomechanical effects (TM) or with thermomechanical effects coupled to enzymatic action (TME), compared with biomass treated in a stirred reactor in the presence of advanced enzymes, $4.6 \% / \mathrm{ms}$, consistency of $30 \%, 70 \mathrm{~min}$, $\mathrm{T}$ : $50{ }^{\circ} \mathrm{C}$ (control). TMO corresponds to the alkalin pretreated coproduct of sweet corn. 


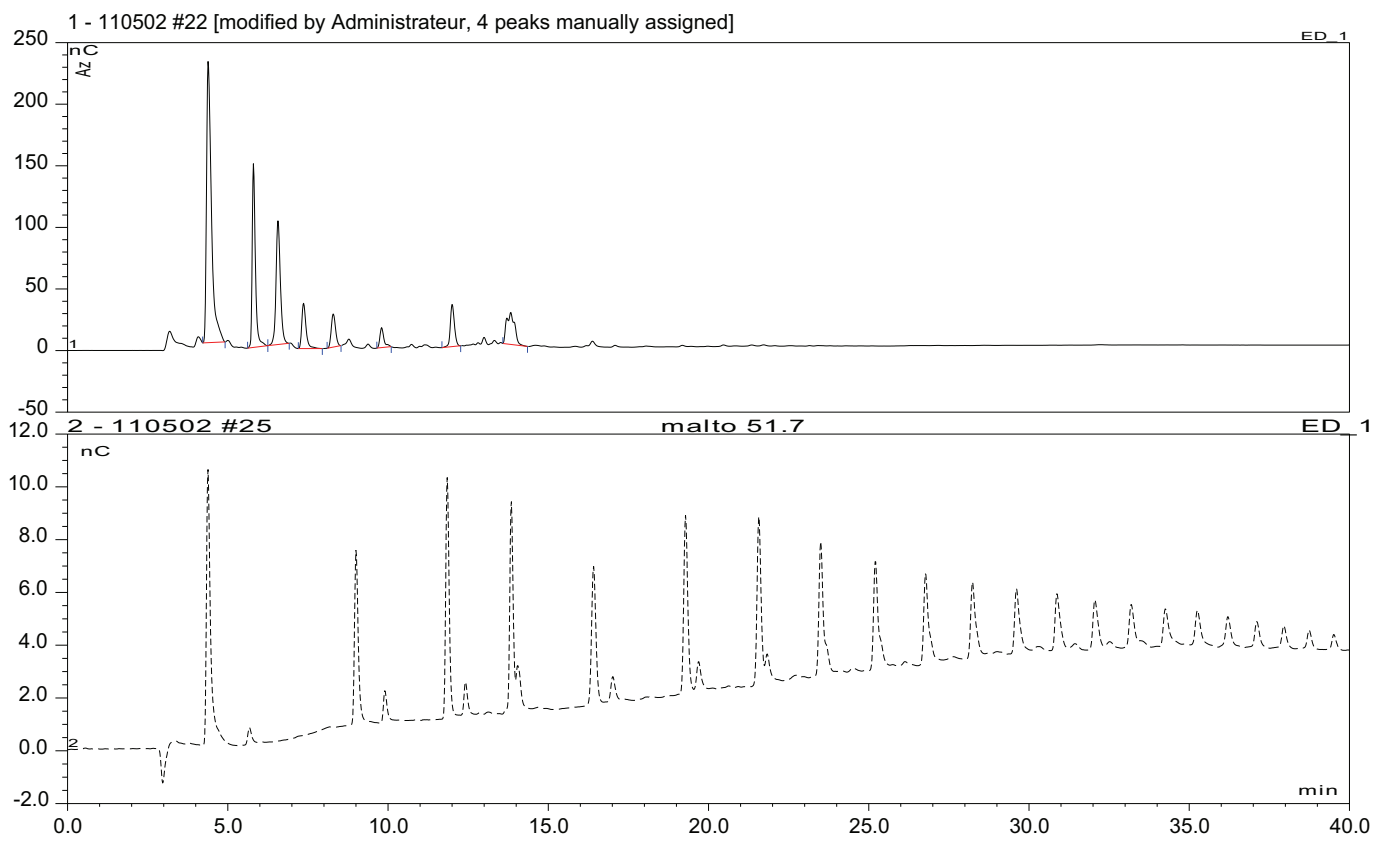

Fig. 6. HPAE-PAD analysis of oligosaccharides released into the filtrate in the seventh cycle of bioextrusion compared with the maltodextrine standard.

During the bioextrusion, free sugars appear, which means that the enzymes are active in the extruder and that monosaccharides are released (1-2\% of dry matter introduced). Analysis of the reducing sugars and of the total sugars in the wash filtrates reveals the presence of sugars released by enzymes in the twin-screw extruder. These sugars are in the form of free sugars, oligosaccharides and polysaccharides, and their proportion increases with the number of passages through the BC21 extruder. Looking at the difference between the proportion of reducing sugars and of total sugars derived from the different determination methods, the DNS method quantifies only the reducing ends of mono, oligo and polysaccharides, whereas the method by acid hydrolysis covers all the monosaccharides in these sugars.

A control is prepared in order to compare the enzymatic action during bioextrusion with the enzymatic action in a stirred reactor. Alkali pretreated biomass is placed in contact with the enzymes in a stirred reactor under the same operating conditions as for the bioextrusion ( $\mathrm{T}: 50^{\circ} \mathrm{C}$, enzyme rate: $4.6 \%, \mathrm{~L} / \mathrm{S}: 2.5$ ) for $70 \mathrm{~min}$. The latter corresponds to the time necessary to achieve the seven passages including the dead time between two successive ones. The sugar released by enzymes after this time in the stirred reactor, is the same in terms of reducing sugars and less in terms of total sugars or free sugars, compared to those obtained in the twin-screw extruder. This reflects the fact that in the case of bioextrusion, the sugars are released in greater amounts in the form of longer chains or in the form of monosaccharides. The difference in the total amount released and the length of sugar chain would seem to show a difference of hydrolytic enzyme action. However, this is probably related to the mixing intensity in the extruder, inducing better penetration of endoglucanases inside the material. Analysis by ion chromatography HPAE-PAD with a Dionex CarboPac PA200 column, confirms the presence of polysaccharides released during bioextrusion (Fig. 6). Compared to standard maltodextrins, these would be oligomers with a low degree of polymerization ( $\mathrm{DP}<6-7)$.

During the bioextrusion, the solubilization of the saccharides is accompanied by a destructuration of the biomass, resulting in an increase in insoluble fine particles carried along in the filtrate when washing the bioextrudate (Fig. 7). This increases with increasing number of passages, and may reflect the effect of breakdown of the biomass by hydrolysis of polysaccharides. Its proportion nearly

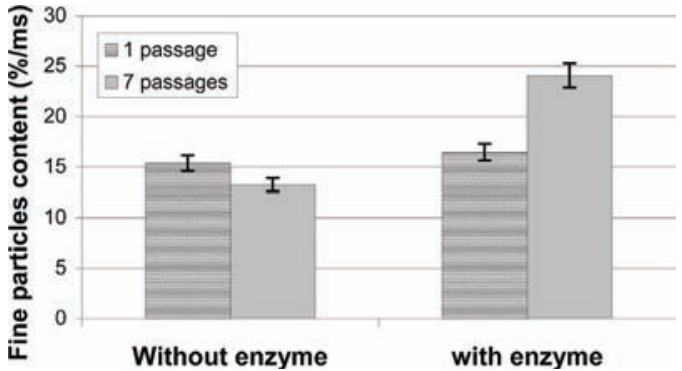

Fig. 7. Fine particles produced by extrusion and bioextrusion in single and multipass mode.

doubled when extrusion was performed in the presence of enzymes for 7 successive passages.

Similarly, the amount of hot water soluble components measured in the bioextrudates increases. It doubles after 7 passages in the presence of enzymes compared to extrusion without enzymes (Fig. 8), confirming the effect of these hydrolytic enzymes in the extruder.

\subsubsection{Modification of ligno(hemi) cellulosic fibers}

The structural modification of the fibers is observed under an electron microscope throughout the pretreatment and bioextrusion steps in the twin-screw extruder (Fig. 9). After pretreatment, the fiber structure appears much wrinkled (Fig. 9b), showing that the fiber surface has released its extractable compounds, and a part of the hemicelluloses and lignin.

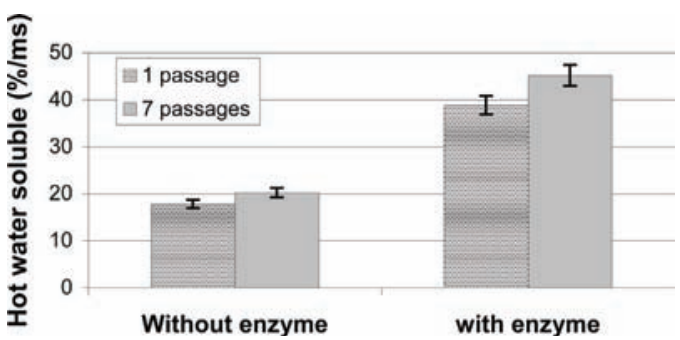

Fig. 8. Hot water solubles after extrusion and bioextrusion in single and multipass mode. 

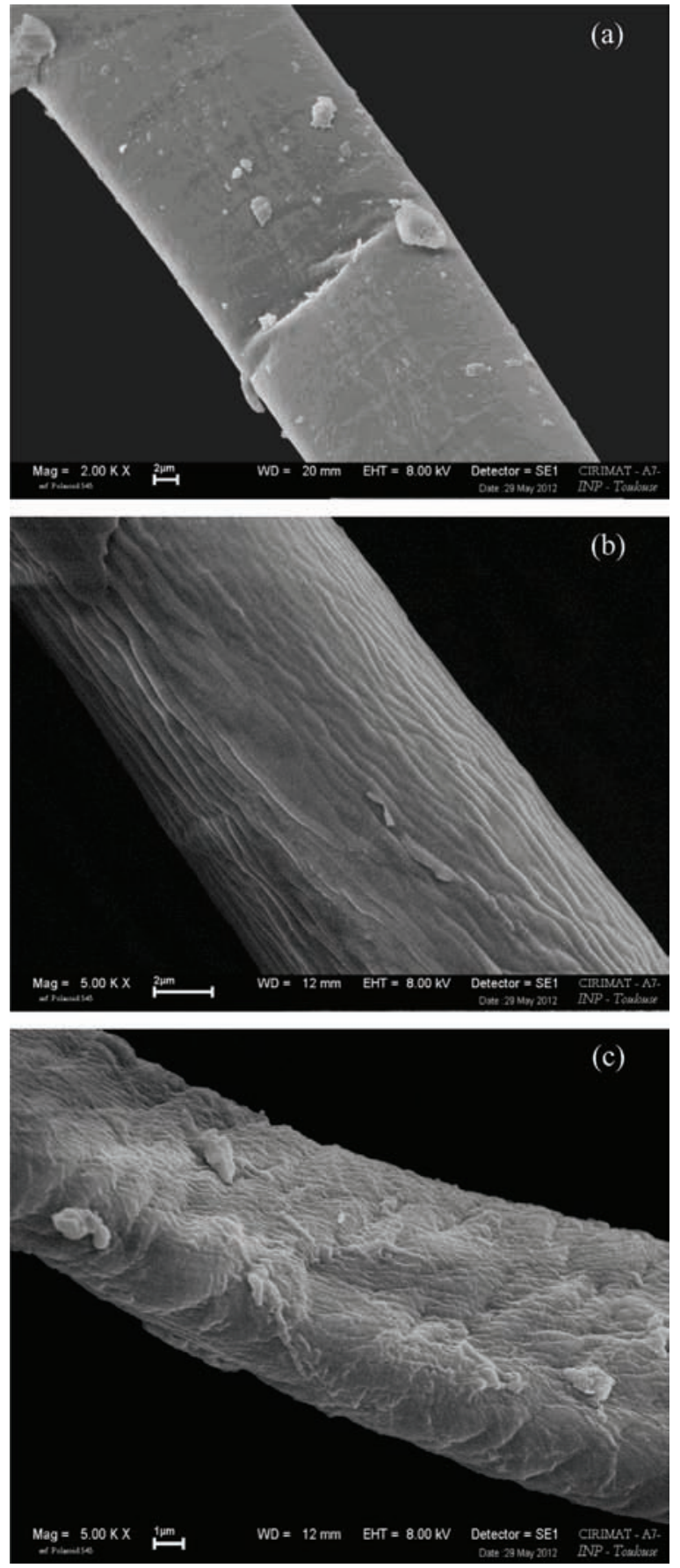

Fig. 9. Scanning electron microscopy (SEM) of fiber observed in case of raw sweet corn coproduct (a), of alkaline pretreated sweet corn coproduct (b), of bioextruded sweet corn coproduct (c).

This extraction of hemicelluloses and lignin is clearing the cellulose microfibrils on the fiber surface.

Following bioextrusion, the action of enzymes in the twin-screw extruder is visible on the surface of the fibers (Fig. 9c), and they appear to be damaged. The enzymes attack the surface of the fiber giving a "peeling" effect caused by a partial depolymerization of the cellulose.

\subsubsection{Modification of the degree of polymerization (DP) of cellulose}

In the paper industry, the degree of polymerization of the cellulose is conventionally evaluated by measuring the viscosity after

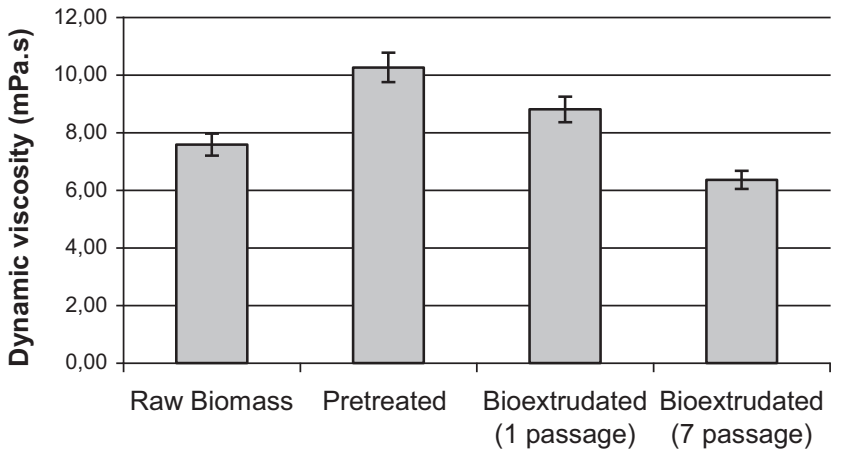

Fig. 10. Evolution of the dynamic viscosity of the sweet corn co-products at different stages of treatment.

dissolving the paper pulp in cupriethylenediamine solution. The greater the degree of polymerization the higher the viscosity of the resulting solution. According to TAPPI T $230 \mathrm{om} 94$ standard, the relationship between the viscosity (intrinsic and dynamic) and the DP is calculated according to the following equations:

$\mathrm{DP}=\left(0.75 \times V^{\prime}\right)^{1.105}$

with $V^{\prime}=(954 \times \log V)-325$

and $V=c \times d \times t$

where

$c=$ constant of the viscometer used; 94 ;

$d=$ density of the working solution, given by the TAPPI T $230 \mathrm{om}$

$t=$ measurement duration (s);

$V^{\prime}=$ intrinsic viscosity $\left(\mathrm{dm} 3 \mathrm{~kg}^{-1}\right)$;

$V=$ dynamic viscosity ( $\mathrm{mPa}$ ).

However, this method, designed for pure cellulose fibers, is not intended to be applied directly to complex materials as is the case for sweet corn coproducts. To minimize interference with the non-cellulosic compounds, materials obtained at each step were purified to isolate their holocellulosic fraction and solubilize the water-solubles and the lignin. The protocol for measuring the viscosity directly in the cupriethylene diamine, applied to holocellulosic fractions of raw material, pretreated extrudates and the bioextrudates, revealed that the viscosity of the solutions increase sharply with the pre-treatment and then gradually decrease with the number of bioextrusion passages (Fig. 10). During pretreatment in the twin-screw extruder, a proportion of hemicelluloses is dissolved, whereas cellulose is not affected, and this proportion of hemicelluloses to cellulose decreases. Nonetheless, hemicelluloses are characterised by a significantly lower degree of polymerisation than cellulose (3-20 times lower) (Klemm et al., 2005; Girio et al., 2010). This results in a higher value of DP for pretreated extrudates compared to raw matter, and explains the higher viscosity measured for the holocellulose from the pretreated biomass. Therefore the decrease in measured viscosity observed with bioextrusion, essentially reflects a shortening of the cellulose chains and confirms the enzyme action during bioextrusion.

\section{Conclusion}

The implementation of a new process of deconstruction of annual plant material in a twin-screw extruder is described using sweet corn co-products. The choice of the profile is explained. The process has been investigated to better understand enzymatic action in the bioextrusion step, and the results obtained in this study prove the hydrolytic action of the enzymes in the extruder. 
The material becomes sticky and less and less textured with successive passages through the extruder. Its rheological properties change and it gradually liquefies. The proportion of sugar released increases with the number of passages.

Oligosaccharides with a low degree of polymerization ( DP <6-7) were released during the bioextrusion. The content of hot water soluble components measured in the bioextrudates, increases.

Partial depolymerization of the cellulose induced a "peeling" on the fiber surface.

The enzyme action during bioextrusion was confirmed by a decrease in measured viscosity of the solubilized bioextrudate in cupriethylenediamine, reflecting in fact a shortening of the cellulose chains.

These results prove that enzymes are active in the extruder and that the process of deconstruction of annual plant material using this apparatus is highly advantageous and could be a very attractive pre-treatment for the production of bioethanol. It enables working with a high consistency, in a high shear environment, over a short time, and initiating enzymatic hydrolysis without excessive dilution. In a subsequent study, the process will be adapted and optimized in one continuous step.

\section{Acknowledgements}

This work has been partially funded by the European Community (Seventh Framework Programme under Grant agreement reference $n^{\circ} 227498$ (BABETHANOL PROJECT)). The authors would like to thank the staff from VTT for the hydrolysability analyses.

\section{References}

Alvira, P., Tomás-Pejó, E., Ballesteros, M., Negro, M.J., 2010. Pretreatment technologies for an efficient bioethanol production process based on enzymatic hydrolysis: a review. Bioresour. Technol. 101 (13), 4851-4861.

Bailey, M.J., Biely, P., Poutanen, K., 1992. Inter-laboratory testing of methods fo assay of xylanase activity. J. Biotechnol. 23, 257-270.

Bailey, M., Nevalainen, K.M.H., 1981. Induction, isolation and testing of stable Trichoderma reesei mutant with improved production of solubilizing cellulase. Enzyme Microb. Technol. 3, 153-157.

Ballesteros, I., Negro, M., Oliva, J.M., Cabañas, A., Manzanares, P., Ballesteros, M. 2006. Ethanol production from steam-explosion pretreated wheat straw. Appl. Biochem. Biotechnol. 130, 496-508.

Bobleter, O., 1994. Hydrothermal degradation of polymers derived from plants. Prog. Polym. Sci. 19, 797-841.

Cara, C., Ruiz, E., Ballesteros, I., Negro, M.J., Castro, E., 2006. Enhanced enzymatic hydrolysis of olive tree wood by steam explosion and alkaline peroxide delignification. Process Biochem. 41, 423-429.

Carvalheiro, F., Duarte, L.C., Gírio, F.M., 2008. Hemicellulose biorefineries: a review on biomass pretreatments. J. Sci. Ind. Res. 67, 849-864.

Chen, W.H., Xu, Y.Y., Hwang, W.S., Wang, J.B., 2011. Pretreatment of rice straw using an extrusion/extraction process at bench-scale for producing cellulosic ethanol. Bioresour. Technol. 102, 10451-10458.

De Vrije, T., de Haas, G.G., Tan, G.B., Keijsers, E.R.P., Claassen, P.A.M., 2002. Pre-treatment of Miscanthus for hydrogen production by Thermotoga elfii. Int. J. Hydrogen Energy 27 (11), 1381-1390.

Duque, A., Manzanares, P., Ballesteros, I., Negro, M.J., Oliva, J.M., González, A. Ballesteros, M., 2014. Sugar production from barley straw biomass pretreated by combined alkali and enzymatic extrusion. Bioresour. Technol. 158, 262-268.

Duque, A., Manzanares, P., Ballesteros, I., Negro, M.J., Oliva, J.M., Sáez, F., Balles-teros, M., 2013. Optimization of integrated alkaline-extrusion pretreatment ofbarley straw for sugar production by enzymatic hydrolysis. Process Biochem. 48, 775-781.

Dziezak, J.D., 1989. Single and twin-screw extruders in food processing. Food Technol. 43, 164-174

Evon, Ph., Vandenbossche, V., Pontalier, P.Y., Rigal, L., 2007. Direct extraction of oil from sunflower seeds by twin-screw extruder according to an aqueous extraction process: feasibility study and influence of operating conditions. Ind. Crops Prod. 26 (3), 351-359.

Ghose, T.K., 1987. Measurement of cellulase activities. Pure Appl. Chem. 59, 257-268.

Girio 1, F.M., Fonseca, C., Carvalheiro, F., Duarte, L.C., Marques, S., Bogel-Łukasik, R., 2010. Hemicelluloses for fuel ethanol: a review. Bioresource Technol. 101 (13), 4775-4800.

Harmsen, P.F.H., Huijgen, W.J.J., Bermúdez López, L.M., Bakker, R.R.C., 2010. Literature Review of Physical and Chemical Pretreatment Processes for
Lignocellulosic Biomass. Wageningen: Wageningen UR Food Biobased Research, (Rapport 1184) $54 \mathrm{p}$.

Himmel, M.E., Ding, S.-Y., Johnson, D.K., Adney, W.S., Nimlos, M.R., Brady, J.W., Foust, T.D., 2007. Biomass recalcitrance. Engineering plants and enzymes for biofuels production. Science 315, 804-807.

Galbe, M., Zacchi, G., 2007. Pretreatment of lignocellulosic materials for efficient bioethanol production. Adv. Biochem. Eng. 108, 41-65.

Han, M., Kang, K.E., Kim, Y., Choi, G.W., 2013. High efficiency bioethanol production from barley straw using a continuous pretreatment reactor. Process Biochem. 48, 488-495

Kang, K.E., Han, M., Moon, S.K., Kang, H.W., Kim, Y., Cha, Y.L., et al., 2013. Optimization of alkali-extrusion pretreatment with twin-screw for bioethanol production from Miscanthus. Fuel 109, 520-526.

Kartika, I.A., Pontalier, P.Y., Rigal, L., 2006. Extraction of sunflower oil by twin-screw extruder: screw configuration and operating condition effects. Bioresour. Technol. 97 (18), 2302-2310.

Karunanithy, C., Muthukumarappan, K., 2011. Optimization of alkali concentration, switchgrass particle size and extruder parameters for maximum sugar recovery using reponse surface methodology. Chem. Eng. Technol. 34 (9), $1413-1426$.

Karunanithy, C., Muthukumarappan, K., 2013. Thermo-mechanical pre-treatment of feedstocks. In: Gu, T. (Ed.), Green Biomass Pretreatment for Biofuels Production.

Klemm, D., Heublein, B., Fink, H.P., Bohn, A., 2005. Cellulose: fascinating biopolymer and sustainable raw material. Angew. Chem. Int. Ed. Engl. 44 (22), 3358-3393.

Kumar, R., Mago, G., Balan, V., Wyman, C.E., 2009. Physical and chemical characterizations of corn stover and poplar solids resulting from leading pretreatment technologies. Bioresour. Technol. 100, 3948-3962.

Lamsal, B., Yoo, J., Brijwani, K., Alavi, S., 2010. Extrusion as a thermo-mechanical pre-treatment for lignocellulosic ethanol. Biomass Bioenergy 34, 1703-1710.

Magro, C., 1995. Valorisation des Pailles de blé par Fractionnement Thermo-Mécano-Chimique dans un Réacteur bivis. INPT, Toulouse http://www.theses.fr/1995INPT057G

Marechal, P., 2001. Analyse des Principaux Facteurs Impliqués dans le Fraction-Nement Combiné de Pailles et de Sons de blé en Extrudeur bi-vis: Obtentiond'agro-Matériaux. INPT, Toulouse http://www.theses.fr/2001INPT031G

Marechal, P., Jorda, J., Pontalier, P.Y., Rigal, L., 2004. Twin-screw extrusion and filtration for xylan production from wheat straw and bran. Paul Gatenholm and Maija Tenkanen Washington (USA) In: Hemicelluloses: Sciences and technology - ACS Symposium Series 864; ED, 864, pp. 38-50.

McIntosh, S., Vancov, T., 2011. Optimisation of dilute alkaline pretreatment for enzymatic saccharification of wheat straw. Biomass Bioenergy 35 (7), 3094-3103.

Miller, G.L., 1959. Use of dinitrosalicylic acid reagent for determination of reducing sugar. Anal. Chem. 31, 426-428.

Mosier, N., Wyman, C., Dale, B., Elander, R., Lee, Y.Y., Holtzapple, M., Ladisch, M., 2005. Features of promising technologies for pre-treatment of lignocellulosic biomass. Bioresour. Technol. 96 (6), 673-686.

N'Diaye, S., 1996. Fractionnement de la Matiere Veígeítale: Mise au Point d'un Proceíde Thermo-Meícano-Chimique et Modeílisation du Reíacteur bi-vis Thesis. INPT, Toulouse France.

N'Diaye, S., Rigal, L., 2000. Factors influencing the alkaline extraction of poplar hemicelluloses in a twin-screw reactor: correlation with specific mechanical energy and residence time distribution of the liquid phase original research article. Bioresour. Technol. 75 (1), 13-18.

Oliva, J.M., Sáez, F., Ballesteros, I., Gónzalez, A., Negro, M.J., Manzanares, P., Ballesteros, M., 2003. Effect of lignocellulosic degradation compounds from steam explosion pretreatment on ethanol fermentation by thermotolerant yeast Kluyveromyces marxianus. Appl. Microbiol. Biotechnol. 105, 141-154.

Rouilly, A., Jorda, J., Rigal, L., 2006. Thermo-mechanical processing of sugar beet pulp. I. Twin-screw extrusion process. Carbohydr. Polym. 66 (1), $81-87$

Saha, B.C., Iten, L.B., Cotta, M.A., Wu, Y.V., 2005. Dilute acid pretreatment, enzymatic saccharification and fermentation of wheat straw to ethanol. Process Biochem. 40, 3693-3700.

Samaniuk, J.R., Scott, C.T., Root, T.W., Klingenberg, D.J., 2011. The effect of high intensity mixing on the enzymatic hydrolysis of concentrated cellulose fiber suspensions. Bioresour. Technol. 102 (6), 4489-4494.

Sluiter, A., Hames, B., Ruiz, R., Scarlata, C., Sluiter, J., Templeton, D., Crocker, D., 2008. Determination of structural carbohydrates and lignin in biomass. In: Laboratory Analytical Procedure.

Sun, Y., Cheng, J., 2002. Hydrolysis of lignocellulosic materials for ethanol production: a review. Bioresour. Technol. 83, 1-11.

Taherzadeh, M.J., Karimi, K., 2008. Pretreatment of lignocellulosic wastes to improve ethanol and biogas production: a review. Int. J. Mol. Sci. 9 1621-1651.

Um, B.H., Choi, C.H., Oh, K.K., 2013. Chemicals effect on the enzymatic digestibility of rape straw over the thermo-mechanical pretreatment using a continuous twin screw-driven reactor (CTSR). Bioresour. Technol. 130, 38-44.

Varga, E., Reczey, K., Zacchi, G., 2004. Optimization of steam pretreatment of corn stover to enhance enzymatic digestibility. Appl. Biochem. Biotechnol. 113-116, 509-523. 
Vandenbossche, V., Doumeng, C., Rigal, L., 2014a. Thermomechanical and thermo-mechano-chemical pretreatment of wheat straw using a twin-screw extruder. BioResources 9 (1), 1519-1538.

Vandenbossche, V., Brault, J., Vilarem, G., Hernández-Meléndezc, O., Vivaldo-Lima, E., Hernández-Luna, M., Barzana, E., Duque, A., Manzanares, P., Ballesteros, M. Mata, J., Castellón, E., Rigal, L., 2014b. A new lignocellulosic biomass deconstruction process combiningthermo-mechano chemical action and bio-catalytic enzymatichydrolysis in a twin-screw extruder. Ind. Crops Prod. 55 (2014), 258-266.

Van Dyk, J.S., Pletschke, B.I., 2012. A review of lignocellulose bioconversion using enzymatic hydrolysis and synergistic cooperation between enzymes-factors affecting enzymes, conversion and synergy. Biotechnol. Adv. 30, 1458-1480.

Van Soest, P.J., Wine, R.H., 1967. Use of detergents in the analysis of fibrious feeds. IV. Determination of plant cell wall constituents. J. AOAC Int. 50, 50-55.

Van Soest, P.J., Wine, R.H., 1968. Determination of lignin and cellulose in acid detergent fiber with permanganate. J. AOAC Int. 51, 780-784.
Yoo, J., Alavi, S., Vadlani, P., Amanor-Boadu, V., 2011. Thermo-mechanical extrusion pre-treatment for conversion of soybean hulls to fermentable sugars. Bioresour. Technol. 102, 7583-7590.

Zhang, S., Keshwani, D.R. Xu, Y., Hanna, M.A., 2012. Alkali combined extrusion pretreatment of corn stover to enhance enzyme saccharification. Ind. Crops Prod. 37, 352-357

Zeitoun, R., Pontalier, P.-Y., Marechal, P., Rigal, L., 2010. Twin-screw extrusion for hemicellulose recovery: influence on extract purity and purification performance. Bioresour. Technol. 101, 9348-9354.

Zheng, Y., Pan, Z., Zhang, R., 2009. Overview of biomass pretreatment for cellulosic ethanol production. Int. J. Agric. Biol. Eng. 2 (3), 51-68.

Zheng, J., Rehmann, L., 2014. Extrusion pretreatment of lignocellulosic biomass: a review. Int. J. Mol. Sci. 15 (18), 967-18984,

http://dx.doi.org/10.3390/ijms151018967. 